УДК-32.001

DOI: 10.17072/2218-1067-2019-3-17-24

\title{
COMPARATIVE ANALYSIS OF CHINA AND RUSSIA'S POSITIONS ON THE UNIFICATION OF THE KOREAN PENINSULA
}

\author{
Cao Huilin \\ Saint Petersburg State University
}

\begin{abstract}
Due to its geography and strategic status, the Korean Peninsula plays an important role in the landscape of Northeast Asia. The problem of a half-century division and unification of the peninsula attracts attention of the countries of Northeast Asia and international forces. Because of the internal affairs and the strategic geographical position of each country, there is a difference of opinions on the unification of the Korean Peninsula. China and Russia are important driving forces to promote the peaceful unification and achievement of peace and development in the Northeast Asia region. The unification will have a significant impact on China, Russia and the entire region. The author analyzes the importance of the strategic position of the Korean Peninsula and the process of its division based on the historical comparative analysis. The paper also considers the effects of the unification of the Korean Peninsula on China and Russia, the same and different positions of China and Russia regarding the unification and presents their views on promoting peace on the Korean Peninsula and stability in Northeast Asia.
\end{abstract}

Keywords: division of the Korean Peninsula; unification of the Korean Peninsula; Northeast Asia; impact of the unification on Russia; impact of the unification on China; standpoint of Russia; standpoint of China.

\section{The division of the Korean Peninsula}

The Korean Peninsula, as a natural channel, connects the mainland and the islands of Japan, and is also a key area where the two forces of land and sea power compete with each other. The Korean Peninsula, as a point of merging the forces and interests of the United States, Japan, China and Russia, has become the geographical and strategic center of Northeast Asia. However, there are potential threats in this region, for example, the United States returns to the Asia-Pacific region, the nuclear crisis on the Korean Peninsula, the division and unification of the peninsula. In this article, we mainly discuss the division and reunification of the Korea

The Korean Peninsula has so far experienced three stages of division. The first stage is the division of territory (1945-1948). The division of Korea Peninsula into North and South territory occurred in 1945 after the defeat of Japan. The United States and the Soviet Union signed an agreement on the joint governance of the country and the Korean Peninsula was divided into two zones of the 38th Parallel Line under the control of the two powers. The second stage is the division of political power (1948-1950). Separate two parts created the Democratic People's Republic of Korea (DPRK) and the Republic of Korea (ROK) in 1948. The third stage is the division of the Korean nation (1950 until now). ROK (under the support of the UN force) and the DPRK (under the support of the Chinese and Soviet forces) signed the Armistice Agreement in 1953, along the non-military zone of the 38th parallel, Korea is divided into two sovereign states with different political systems. The united nation was completely divided.

The Korean reunification plan is the main part of the policy of the ROK and it is based on developing a unified strategy. For the DPRK, the most urgent tasks at present are to ensure the survival and development of the country, to increase economic power, to improve relations with South Korea, to strengthen internal solidarity, and together with the ROK to promote the process of uniting the Korean Peninsula. The DPRK and the ROK strive to achieve the ultimate goal - union. So far, there has been a period of mutual peaceful coexistence between them, active joint development and cooperation, and at the same time there are also periods of heightened tension. Between them there is a regular meeting of leaders to address current issues of the peninsula. However, effective consensus has not yet been reached. Therefore, the path of association is still far away.

(C) Cao Huilin, 2019 
A historic moment was the meeting without interference between the Kim Jong-un and Moon Jae-in in 2018. It was also the first meeting between the two leaders in a decade. They signed a declaration and announced that both parties would make every effort to implement the mechanism of denuclearization and suspension of activities on the Korean Peninsula. Obviously, this meeting contributed to reducing the level of military tensions and accelerating progress of peaceful coexistence.

Despite the fact that the two countries did not achieve the desired results in a series of meetings, which cannot be underestimated, they show that two countries always seek direct dialogue and cooperation without external interference, hope to improve the current situation, as well as achieve peaceful coexistence. DPRK and ROK did not play a dominant role in the Cold War, however, they are the main forces in resisting the hegemonic order to search for national unity.

\section{The impact of the Korean unification on China and Russia}

The Korean Peninsula, located in East Asia, extends south of the Asian continent for approximately $1,100 \mathrm{~km}$ (683 miles), on both sides clamped by the marginal seas of the Pacific Ocean. In the north, the peninsula borders with China and Russia. The stability of the Korean Peninsula contributes to the peace and stability of the Northeast Asia, especially, it also plays an unusual role in this region and even in international relations in the Asia-Pacific region. The peaceful unification of Korea will be useful to all parties. However, there are still no specific ways and methods for implementing peaceful unification. As for influences on Russia and on China, in a word, Korean unification is both a positive factor and a negative factor for the interests of the two countries. In the article the following four hypothetical types of unification will be identified.

Maintain the status quo. If the status quo on the peninsula is maintained, China and Russia should always adhere to the path of peaceful development of the peninsula, moreover, advocate political dialogue, multilateral coordination and peaceful resolution of all conflicts on the peninsula. China and Russia should help the DPRK in the near future to become a normal member of the international community, make efforts to develop its relations with the US, as well as coordinate diplomatic relations between the DPRK and its neighboring countries. In addition, they still need to accelerate the active participation of all parties, resume the six-party talks as soon as possible and implement a "double suspension" strategy, that is, "for North Korea to renounce possession of nuclear weapons, and for the US withdrawal of troops", ultimately, turn the Northern Korea to a strategic buffer zone for US balance.

The Republic of Korea absorbs the DPRK. United Korea will develop in accordance with the capitalist line. The ROK differs from China and Russia in ideology, but it has the same values as the US and Japan. Some Russian political scientists believe that when the ROK absorbs the DPRK, it will force the DPRK to become a buffer between China and the PK. However, in this case, the danger moves to the territory of China and Russia (Bogdan, 2018). Many Chinese experts also believe that the unification of the peninsula will pose a serious threat to China, mainly because the US forces will cover the entire peninsula (Deng Xiaochuan, 2017). China always believes that the US-South Korean alliance is a product of the Cold War (Xu Guanghe,2014), since the "rebalancing strategy in the Asia-Pacific region" of the US constantly strengthens the system of the US-South Korean alliance, which mainly aims to balance and weaken the growing influence of China. In addition, the US, Japan, and South Korea are likely to continue to strengthen their alliances. Obviously, NATO will expand eastward. The US will further strengthen its power in Northeast Asia, thus the strategic balance of this region will again be disrupted. As a result, the national security interests of China and Russia will be affected.

North Korea absorbs the Republic of Korea. United Korea will develop according to a socialist model. Under the influence of the Cold War ideology, a united Korea will further strengthen its ties with China and Russia in order to gradually reduce US influence in Northeast Asia, complete the withdrawal of US troops, as well as remove the existence of the US-South Korean alliance. If this happens, the strategic space of the US and Japan will also be compressed, and the implementation of the goal of a regional power for Japan will become more difficult. The US and Japan will become countries that strongly oppose Korean unification.

Peaceful coexistence of two Korean states. The two countries will achieve independent development, recognize each other, as well as jointly develop a neutral model that matches the national conditions of the country. It seems that this type of association is the most acceptable option. A stable, neutral, and united Korea meets the national interests of China and Russia and is also a necessary condition for maintaining peace in Northeast Asia. 
According to the Russian expert Bogdan, "if the united Korea becomes a state independent of the US, the positive side will increase. American military bases will be withdrawn. Integration will become the fact that the entire Korean Peninsula will turn into a state that, having a powerful South Korean economy and strong North Korean military potential, will become another major regional player and we can hope that this country will be an ally of China and the Russia" (Bogdan, 2018).

From the point of view of geopolitical factors and the national strategy, the independent unification of the peninsula not only corresponds to the foreign policy of Russia of the "Pivot to the east", but also increases Russia's influence on the territory of Northeast Asia. The Korean Peninsula can be viewed as the key to realizing the line of Russia to strengthen its position in the dynamically developing Asia-Pacific region of the XXI century (Toloraya, 2014). By strengthening cooperation with the two countries of the peninsula, Russia can increase its influence on the affairs of the Korean Peninsula, thus restrain the influence of China, the US and Japan in Northeast Asia. From the point of economic development, the unification of the peninsula is a long-term interest of Russia. There are not territorial conflicts among Russia, the DPRK and the ROK, what's more, there are many interactions in the economic sphere.

South Korea has advantages in capital, information, technology, management, etc., Russia is rich in natural resources, while, North Korea has a lot of human resources. Russia can strengthen cooperation in the development of resources, deposits, construction of infrastructure, as well as trade with united Korea and the countries of the Northeast Asia. For Russia, trans-Asian transit through large-scale multilateral cooperation projects to joint with the DPRK and the ROK is a challenge, and ultimately, Russia needs to restore the rail link between the DPRK and the ROK. The unification of the Korean Peninsula will necessarily speed up the process of this project, finally it will accelerate the economic recovery in Siberia and the Russian Far East as soon as possible.

As for China, it borders on the Korean Peninsula, therefore, the stability of the peninsula will pose a direct threat to Northeast China. First of all, the unification will undoubtedly lead to the solution of the North Korean nuclear issue, which will ensure a stable external environment for China. In addition, some scientists believe that the unification will also provide experience for the unification of mainland China and Taiwan. After the unification, the resources of the North Korean and the South Korean will be united, therefore, bilateral and multilateral economic exchange between China and the peninsula will also gradually increase. China can get more economic benefits from a united Korea. Cooperation between them will facilitate the process of economic and trade investment, contribute to the economic development of North Korea and improve people's living conditions. At the same time, this will also accelerate the recovery of the old industrial base in Northeast China, contributes to the implementation of the interfacing of the "One Belt and One Road" initiative and the "Eurasian Economic Initiative". In addition, after the unification, the entire Korean Peninsula can join the current process of tripartite cooperation among China, Japan and South Korea which aim to implement regional integration in Northeast Asia as soon as possible.

However, there is also a negative view on reunification. Some scholars believe that no matter how Korea is united, it will not contribute to economic development. Because united Korea will focus its investments on building infrastructure like roads and railways in North Korea. And thus, the united peninsula will become a competitor to China.

In our opinion, there are many challenges on the road to the reunification of the Korean peninsula. On the one hand, in the event of a conflict between the two countries, refugees from the DPRK will pour into northeastern China and Russian Far East, which will affect their normal economic activities, even security and stability. On the other hand, if the Korean Peninsula cannot completely abandon nuclear weapons, which will undoubtedly increase the pressure on Japan and also stimulate Japan to research and develop in the field of nuclear weapons. Experts believe that nothing can stop this country from developing all types of nuclear weapons, simulating tests and establishing their mass production as soon as possible with its highly developed science and advanced technology (Tkachenko, 2000). And thus, the arms race in Northeast Asia will intensify again, moreover, peace and stability around China and Russia will face serious challenges.

\section{Standpoint of Russia and China on the unification of the Korean Peninsula}

As two major economies possess a special geopolitical strategic position in the Northeast Asia region, China and Russia play a key role in facilitating the settlement of affairs on the Korean Peninsula. Without the active participation of large countries such as China and Russia, it is difficult for North Korea to obtain the necessary security guarantees and needs. 
Russia's standpoint on uniting the Korean Peninsula is based on its geopolitics and economic interests, certainly, security interests will be the most important aspect. Rather, the strategic goal of Russia on the peninsula is based on maintaining peace and stability of the peninsula, maximizing its economic benefits and expanding influence on solving the problem of the peninsula (Liu Qingcai, 2013). The security and stability of the Korean Peninsula directly affect the stability of the Russian Far East. Balancing American and Chinese influence is also a long-term objective for Russia. Thus, Russia has always been proceeded from the fact that a united Korea, however, unification is possible only by peaceful means, should be democratic and peaceful, besides, build its relations with neighbors and other members of the international community on the basis of international legal principles, the UN Charter and etc. (Denisov, 2009).

Russia's standpoint on supporting the reunification in different times is also different. Russia has always been interested in uniting the Korean Peninsula and has constantly strengthened its political and economic ties with the DPRK and the ROK. During the Cold War, Russia and North Korea maintained friendly and allied relations, certainly, Russia supported the DPRK' plan to unify the peninsula. Moscow has repeatedly advocated the unification on a socialist basis and the conditions for the preservation of allied relations with the USSR (Zabrovskaya, 2014). The Agreement, signed in 1961, states that Both the Soviet Union and north Korea believe that the unification should be made on a peaceful and democratic basis, in this way, the solution meets both the national interests of the Korean people and the cause of maintaining peace in the Far East ${ }^{1}$. Pyongyang until the end of the 1980 s believed that the only thing was to choose the right moment to capture the South (Toloraya, 2010). After the end of the Cold War, especially after the collapse of the Soviet Union, Russia and ROK established diplomatic relations. We can find the Russia's standpoint after the visit of President B.N. Yelitsin in Seoul in 1993, he maintained that the unification should be possible through a dialogue between the North and the South of Korea. In addition, a "Joint Russian-Korean declaration" was signed in 1997, and stated the Russian standpoint that Moscow adhered to the peaceful democratic unification and the establishment of a dialogue between the ROK and the DPRK on the basis of the "Agreement on reconciliation, non-aggression, exchanges and cooperation" of 1991.

Putin's foreign policy and his speeches in various cases are good to illustrate the Russia's attitude toward unification. Putin supports unification, which should rest on peace. He noted that "Russia is ready to use the potential relations with South and North Korea to facilitate an inter-Korean settlement. It should adhere to the following positions: 1) The peace process and cooperation between the North and the South should be developed on the principles agreed by the Korean people themselves without outside interference. 2) All problems should be solved exclusively by peaceful diplomatic means in the spirit of the joint declaration of the South and the North in June 2000. 3) Russia welcomes the process of creating a peaceful united Korean state, friendly to Russia and other countries. 4) Reducing tension is impossible with the proliferation of weapons of mass destruction in the world in general and in the region in particular, and on the Korean Peninsula all the more. 5) Russia is interested in the implementation of projects aimed at the economic development of the region with the participation of the countries of North-East Asia, including the two Koreas ${ }^{2}$. In his opinion, such principles and joint affairs lay a solid economic foundation for stability in the region, as well as contribute to the development of the economy of Siberia and the Russian Far East. In addition, Russia welcomed the resumption of the inter-Korean dialogue in early 2018, as well as directly dialogue between the DPRK and the US.

In recent years, great changes have taken place in the international situation. The Asia-Pacific region is becoming increasingly important in world politics and economics, the US has proposed a strategy for rebalancing forces in the Asia-Pacific region, The Ukrainian crisis has intensified and the latest is getting worse, and at the same time Russia has been subject to sanctions from Western Europe. Therefore, Russia's strategy is actively moving east. Moreover, Russia's attitude to the issue of Korean reunification has also become more active. In the long range, Russia supports the peaceful Korean reunification, owing to the process of unification, Russia can use its mediator status to regain its influence on the peninsula, and the united peninsula can play its part in balancing Japan. Moreover, Russia is interested in the implementation of economic projects on the Korean Peninsula, which is impossible without normalizing North-South relations. Only the normalization of inter-Korean relations will remove one of the obstacles to the creation of a multilateral system of cooperation and security in Northeast Asia (Valkovich, 2018). Russian experts believe that in that

\footnotetext{
${ }^{1}$ URL: ttps://ru.wikisource.org/wiki/Договор_о_дружбе,_сотрудничестве_и_взаимной_помощи_между_СССР_и_КНДР (дата обращения: 02.12.2018).

2 Путин В. В. Выступление в Национальном собрании Республики Корея. URL: http:/www.kremlin.ru/events/ president/transcripts/21196 (дата обращения: 03.12.2018).
} 
situation it is important for Russia to ensure a "soft" and gradual process in uniting Korea and avoiding a "landslide" path with its negative consequences for regional security (Zabrovskaya, 2014).

China always adheres to the unchanged position on the Korean Peninsula, always adheres to the denuclearization of the peninsula, supports the dialogue between the DPRK and the US on the settlement of the peninsula, improves relations between the North and the South, as well as a peaceful solution to the North Korean nuclear problem. China declared its standpoint in the "Joint Communique" in 1992 on the Korean reunification: the Chinese Government respects the Korean people's desire for the soonest peaceful Korean reunification and supports that the Korean people themselves implement the peaceful reunification ${ }^{1}$.

In 2001, when meeting with senior leaders Kim Jong Un in Beijing, then chairman Jiang Zemin noted that China is a close neighbor of the Korean Peninsula and has always been committed to maintaining peace and stability on the peninsula. China will continue to support the positive efforts of the North and the South to further improve relations and achieve independent peaceful reunification. Besides, China will welcome and support North Korea to improve and normalize relations with other countries ${ }^{2}$.

$\mathrm{Hu}$ Jintao stressed that as a close neighbor of the Korean Peninsula and a mutual friend of the DPRK and the ROK, China always hopes and supports the North and the South in improving relations, reconciliation and cooperation through dialogue and consultation, and finally, in achieving independent and peaceful reunification ${ }^{3}$.

On January 23, 2013, at a meeting with Ambassador Extraordinary and Plenipotentiary Kim Wu Sing, Xi Jinping emphasized that maintaining peace and stability on the Korean Peninsula is in the fundamental interests of China and South Korea. The Chinese side is in favor of a balanced solution to the problems of all parties through dialogue and consultations, and also hopes that the six-party talks will be resumed soon. China supports the achievement of independent and peaceful reunification on the peninsula, furthermore, is always ready to play an active role in this process ${ }^{4}$.

During his meeting with Kim Jong Un, Xi Jinping expressed his willingness to continue working with all interested parties to play a positive role in fully advancing the process of peace negotiations on solving the problems of the peninsula, as well as in ensuring long-term stability in the region ${ }^{5}$. When the situation on the peninsula is tense, China is making unremitting efforts to ease tensions, and also promptly urges the North and the South to remain calm, to engage in dialogue as soon as possible in order to prevent wars and disrupt peace on the peninsula. At the same time, China also calls on all interested parties to strengthen coordination and to attach international forces in order to jointly protect peace and stability in this region. By analyzing the standpoint of Chinese officials, we found that in the end a peaceful and united peninsula will provide a stable and prosperous international situation in Northeast Asia.

However, in scientific circles there is a different view on the unification. According to the analysis of the study, Chinese scientists mainly adhere to two opinions. 1) Support the reunification. Some people support the independent and peaceful unification, which is in line with China's strategic interests. Otherwise, a united Korea will help ensure stable and peaceful conditions for the modernization of China, moreover, it will help China to develop friendly cooperation relations and bilateral and multilateral trade and economic relations with it (Chen Xiangyang, 2012). On the other hand, the peaceful reunification of the Korean Peninsula will undoubtedly contribute to the peaceful reunification of China (Zhang Liangui, 2003). Among them, the minority of people support that the North should be taken over by the South. If so, they consider that South Korea, of course, should take on various obligations to China in exchange for China's support, such as the withdrawal of American troops from the peninsula, the adjustment of the US alliance and even canceling and etc. 2) Some experts are skeptical of unification. They mainly analyze some of the difficulties that the peninsula may face, such as the nuclear fate of the DPRK, the economic integration of a united Korea, the

Китайско-корейское совместное коммюнике об установлении дипломатических отношений. URL: http://news.cctv.com/special/C18129/20070405/103444.shtml (дата обращения: 01.12.2018).

${ }^{2}$ Генеральный секретарь Цзян Цзэминь пригласил Генерального секретаря Ким Чен Ира совершить неформальный визит в Китай. URL: http://www.people.com.cn/GB/paper39/2522/380084.html (дата обращения: 12.12.2018).

${ }^{3}$ Ху Цзиньтао принимает интервью с американскими СМИ по таким вопросам, как Корейский полуостров. 18.01.2011 г. «Жэньминьжибао». URL: http://xian.qq.com/a/20110118/000095.htm (дата обращения: 01.12.2018).

${ }^{4}$ Си Цзиньпин: Поддержание мира и стабильности на Корейском полуострове соответствует коренным интересам Китая и Южной Кореи. Время: 23 января 2013 г. CCTV. URL: http://news.cntv.cn/2013/01/23/ARTI1358938708200235.shtml (дата обращения: 01.12.2018).

Си Цзиньпин и Ким Чен Ын провели встречу в Даляне. Синьхуа. 10 мая 2018 г. URL: http://www.chinadaily.com.cn/ interface/yidian/1139302/2018-05-10/cd_36173458.html (дата обращения: 01.12.2018). 
democratic political consolidation of Korea, the high economic costs of South Korea, as well as geopolitical changes in Northeast Asia and etc (Yu Yingli, 2013).

At present, China's standpoint on the unification of the Korean Peninsula is still in the process of settlement. Considering the current situation, maintaining the status quo is the only choice (Deng Xiaochuan, 2017). Some foreign experts are equally insistent, China will not want to see North Korea unity with South Korea. The Chinese government would prefer to keep the Korean Peninsula divided and to maintain the North as a strategic buffer while keeping the South as a trade and strategic partner (Hwang, 2010).

According to our point of view, China's actual attitude to the issue of unification still depends on regional and external factors. China hopes that the unification will not affect the stability of the Korean peninsula or even northeast Asia. China does not support unification under external intervention, such as the US or Japan, as well as not advocate unification by military forces and always adheres to peace negotiations.

China and Russia have the same standpoint on the issue of unification on the Korean Peninsula, even though, the initial goals of the two countries are different. The priority of China's policy is to maintain peace and stability on the peninsula with an emphasis on security. The initial development of Russia's relations with South Korea was aimed at developing the economy of the Far East and Siberia. On the basis of the Russian policy of "equidistance", Russia is currently focusing on strategies for simultaneously promoting the economy and security. China and Russia should always insist that peace on the Korean Peninsula is a prerequisite for uniting the Korean Peninsula, and actively mobilize the major powers to help improve relations between the North and the South.

\section{Conclusion}

The unification of the Korean Peninsula is always the highest strategic goal pursued by the DPRK and the ROK, as well as the goal of both countries to become independent powers, to a large extent is the only way to achieve national autonomy. The implementation of the association is not only related to the goal of the DPRK and the ROK, but also to the direction of joint efforts of the major countries in the region and the interests of the all parties.

It is vital to note that the key to be peace is the proper and balanced solution of the concerned problems of all parties, as well as the promotion of the denuclearization of the peninsula and the establishment of a peaceful mechanism on the peninsula. Various countries are also making active efforts to help to resolve the North Korean nuclear issue, the most important of which is a series of talks aimed at resolving the North Korean nuclear issue, involving North Korea, South Korea, China, the United States, Russia and Japan. Therefore, China and Russia should always adhere to their standpoint on unification and goals of the denuclearization of the Korean Peninsula and never fluctuate.

\section{Финансовая поддержка}

This article is funded by China scholarship council

此项目得到中国国家留学基金委的资助

\section{Reference}

Богдан, Б. А. (2018) 'Эксперты сомневаются в возможности объединения Кореи', Hoвые известия, 28 апреля. URL: https://newizv.ru/news/world/28-04-

2018/eksperty-somnevayutsya-vvozmozhnosti-ob-edineniya-korei (дата обращения: 07.12.2018). [Bogdan, B. A. (2018) 'Experts doubt about the possibility of uniting Korea' [Eksperty somnevayutsya v vozmozhnosti ob"edineniya Korei], Novye Izvestia, April 28. Available at: https://newizv.ru/news/world/28-042018/eksperty-somnevayutsya-vvozmozhnosti-ob-edineniya-korei (Accessed: 17 December 2018). (In Russ.)].
Толорая, Г. Д. (2018) Корейский полуостров: вызовы и возможности для России [электронный pecypc]. URL: http://www.perspektivy.info/book/korejskij_ poluostrov_vyzovy_i_vozmozhnosti_dla_ rossii_2010-12-08.htm (дата обращения: 07.12.2018) [Toloraya, G. D. (2018) The Korean Peninsula: Challenges and Opportunities for Russia [Koreiskii poluostrov: vyzovy i vozmozhnosti dlya Rossii] [online]. Available

at: http://www.perspektivy.info/book/korejskij_ poos-

trov_vyzovy_i_vozmozhnosti_dla_rossii_20 10-12-08.htm (Accessed: 07 December 
Валькович, Е. И. (2018) 'Ситуация на Корейском полуострове и безопасность в регионе СВА' в: Восточный альманах: сб. науч. ст. Вып. II / под общ. ред. Т.А. Закаурцевой; ред. кол.: А.Т. Мозлоев, О.А. Добринская, А.К. Галимзянова. Москва: Дипломатическая академия: Квант Медиа, 154 c. [Val'kovich, E. I. (2018) 'The situation on the Korean Peninsula and security in the Northeast Asia region' [Situatsiya na Koreiskom poluostrove i bezopasnost' $\mathrm{v}$ regione SVA] in: Zakaurtseva T.A. (ed.) East almanac: collection of scientific articles [Vostochnyi Al'manakh: sb. nauch. st.], issue II. Moscow: Diplomaticheskaya Academiya: Kvant Media Publ., 154 p. (In Russ.)].

Денисов, В. И. (2009) 'Россия на Корейском полуострове: проблемы и перспективы', Аналитические записки, 5(45), июнь. Москва: МГИМО - Университет, 21 с. [Denisov, V. I. (2009) 'Russia on the Korean Peninsula: Problems and Prospects' [Rossiya na Koreiskom poluostrove: problemy i perspektivy], Analiticheskie zapiski, 5(45), June. Moscow: MGIMO University Publ., 21 p. (In Russ.)].

Забровская, Л. В. (2014) 'Корейские концепции объединения страны и позиция России', Россия и АTP, 2(84). [Zabrovskaya, L. V. (2014) 'Korean conceptions of the reunification and Russia's position' [Koreiskie kontseptsii ob"edineniya strany i pozitsiya Rossii], Russia and the Pacific, 2(84). (In Russ.)].

Ткаченко, В. П. (2000) Корейский полуостров и интересы России. Москва: Издательская фирма «Восточная литература» РАН. 207 c. [Tkachenko, V. P. (2000) Korean peninsula and Russia's interests [Koreiskii poluostrov i interesy Rossii]. Moscow: 'Vostochnaya Literatura' RAS Publ., 207 p. (In Russ.)].

Толорая, Г. Д. (2014) 'Россия и проблемы Корейского полуострова на современном этапе', Вестник МГИМО, 4(37). [Toloraya, G. D. (2014) 'Russia and the issues of the Korean Peninsula' [Rossiya i problemy Koreiskogo poluostrova na sovremennom etape], MGIMO Review of International Relations, 4(37). (In Russ.)].
2018). (In Russ.)].Hwang, Eui-Gak (2010) The Search for a Unified Korea: Political and Economic Implications. New York, NY: Springer New York.

陈向阳.中国对朝鲜半岛统一政策浅析 [J].亚非纵 横,2012(05):21-24. [Chen Xiangyang (2012) 'A brief analysis of China's policy on the reunification of the Korean peninsula [J]', Yafei Zongheng, 05, pp. 21-24. (In Chinese)].

邓晓川.东北亚大国的朝鲜半岛政策与东北亚战略 格局[J].厦门特区党校学报,2017(04):15-20.

[Deng Xiaochuan (2017) 'Korean peninsula policy and northeast Asia strategic pattern of northeast Asian powers [J]', Journal of the Party School of Xiamen Special Economic Zone, 04, pp. 15-20. (In Chinese)].

刘清才等

21世纪初俄罗斯亚太政策研究[M].北京: 社会科学文献出版社, 2013.12. [Liu Qingcai et al. (2013) Russia's Asia-pacific policy research in the early 21 st century [M]. Beijing: Social sciences academic press, 12. (In Chinese)].

习近平: 《中国高度重视中朝友好合作关系》, 载《人 民日报》海外版, 2018 年 6 月 20 日, 第 1 版. [Xi Jinping (2018) 'China attaches great importance to China-DPRK friendly and cooperative relations', overseas edition of People's Daily, June 20, 1st edition. (In Chinese)].

徐光河.鲜半岛统一与东北亚国际政治的关系[D]. 延边大学,2014. [Xu guanghe (2014) Reunification of the Korean peninsula and international politics in northeast Asia [D]. Yanbian university. (In Chinese)].

于迎丽. 中国周边战略与朝鲜半岛统一前景 [J]. 辽 东学院学报(社会科学版),2013,15(05): 1016. [Yu Yingli (2013) 'China's neighborhood strategy and prospects for the reunification of the Korean peninsula [J]', Journal of Liaodong University (social science edition),15(05), pp. 10-16. (In Chinese)].

张琏瑰, “朝鲜半岛南北双方统一政策演变和南 北关系”, 《韩国研究论从》, 2003 年, pp42-51. [Zhang Liangui (2003) 'The evolution of the reunification policy between the north and the south of the Korean peninsula and the relations between the north and the south', South Korea Studies, pp. 42-51. (In Chinese)]. 


\title{
Информация об авторе
}

Цао Хуэйлинь - аспирант, факультет политологии, С.-Петербург. государственный университет. E-mail: huilin369@163.com (ORCID: 0000-0003-4371-6079. ResearcherID: S-1355-2018).

Статья принята к печати: 15.06.2019

\section{СРАВНИТЕЛЬНЫЙ АНАЛИЗ ПОЗИЦИЙ КИТАЯ И РОССИИ ПО ОТНОШЕНИЮ К ОБЪЕДИНЕНИЮ КОРЕЙСКОГО ПОЛУОСТРОВА}

\author{
Цао Хуэйлинь \\ Санкт-Петербургский государственный университет, Россия
}

\begin{abstract}
Аннотация
Благодаря своему геополитическому положению и стратегическому статусу, Корейский полуостров играет важную роль в ландшафте современной Северо-Восточной Азии (СВА). Проблема полувекового раскола и объединения Корейского полуострова привлекает внимание как политиков стран Северо-Восточной Азии и международных сил, так и экспертов-аналитиков. В современном публичном дискурсе можно выделить различия в позициях по вопросу об объединении Корейского полуострова. Наиболее влиятельными сторонами в обсуждении этого вопроса являются Китай и Россия, правительства которых публично декларируют свою позицию содействия мирному объединению Корейского полуострова и достижению мира и развития в регионе Северо-Восточной Азии. Потенциально объединение Корейского полуострова значимо для Китая, России и, в общем, всего региона СВА. На основе сравнительного исторического анализа в статье обсуждается важность стратегического положения Корейского полуострова и особенности процесса раскола полуострова; выявлены и объяснены влияние объединения Корейского полуострова и на Китай, и на Россию; рассмотрена вариативность позиций Китая и России в отношении объединения.
\end{abstract}

Ключевые слова: раскол Корейского полуострова; объединение Корейского полуострова; СевероВосточная Азия; влияние объединения на Россию; влияние объединения на Китай; позиции России; позиции Китая. 